\title{
Pengembangan Strategi Pembelajaran Kontekstual Mata Kuliah Fotografi Pendidikan Program Studi Teknologi Pendidikan Universitas Negeri Jakarta
}

\author{
Muhammad Fatih Abiyyu, ${ }^{1 \otimes}{ }^{\text {Robinson Situmorang }}{ }^{2}$, Murti Kusuma Wirasti ${ }^{2}$ \\ ${ }^{1}$ Universitas Negeri Jakarta, Jakarta, Indonesia. \\ ${ }^{2}$ Universitas Negeri Jakarta, Jakarta, Indonesia. \\ 3 Universitas Negeri Jakarta, Jakarta, Indonesia.
}

DOI: https://doi.org/10.21009/JPI.041.o8

\begin{abstract}
Article History Abstrak
Submitted: 2021

Accepted : 2021

Published : 2021

\section{Keywords}

Instructional Strategy; Contextual Teaching and Learning; Photography; Dick \& Carey Model

Penelitian pengembangan ini bertujuan untuk menghasilkan produk berupa Rencana Perkuliahan Semester (RPS) dengan menerapkan strategi pembelajaran kontekstual dan modul satuan pembelajaran di Program Studi Teknologi Pendidikan Universitas Negeri Jakarta. Dalam penelitian pengembangan ini mengacu pada model Dick\&Carey yang terdiri atas: Identify Instructional Goal(s), Conduct Instructional Analisis, Analyze Learners and Context, Write Performance Objective, Develop Assessment Instrumen, Develop Instructional Strategy, Develop and Select Instructional Materials, Design and Conduct Formative Evaluation of Instruction, and Revise Instruction. Produk penelitian pengembangan ini telah melalui tahap evaluasi formatif, yaitu expert review dan one to one. Hasil dari Expert Review dari ahli desain pembelajaran memperoleh nilai 3,75 (sangat baik). ahli materi sebesar 2,9 (baik), dan dari ahlli media mendapatkan skor 3,85 (sangat baik). Evaluasi pengguna (one to one) dilakukan kepada pengguna yaitu dosen pengampu dan mahasiswa. Evaluasi one to one oleh dosen pengampu mendapatkan nilai 3,57 (sangat baik) dan evaluasi yang dilakukan oleh mahasiswa mendapatkan nilai 3,7 (sangat baik). Berdasarkan hasil teresebut, dapat disimpulkan bahawa produk Rencana Perkuliahan Semester mata kuliah fotografi Pendidikan dan modul satuan pembelajaran sangat baik.
\end{abstract}

\section{Abstract}

This development research aims to produce a product in the form of Rencana Perkuliahan Semester (RPS) by implementing contextual learning strategies and learning unit modules in the Education Technology Study Program at the State University of Jakarta. In this research development refers to the Dick \& Carey model which consists of: identifying Instructional Goal (s), Conduct Instructional Analysis, Analyze Learners and Context, Write Performance Objective, Develop Instrument Assessment, Develop Instructional Strategy, Develop and Select Instructional Materials, Design and Conduct Formative Materials Evaluation of Instruction, and Revise Instruction. This development research product has gone through the formative evaluation stage, namely expert review and one to one. The results of the Expert Review from the learning design expert obtained a value of 3.75 (very good). material expert of 2.9 (good), and from media expert got a score of 3.85 (very good). Then the user evaluation (one to one) was conducted to users namely lecturers and students. One to one evaluation by lecturers received a score of 3.57 (very good) and evaluations conducted by students get a value of 3.7 (very good) .Based on these results, it can be concluded that the Rencana Perkuliahan Semester product in Education photography courses and learning unit modules is very good.

\footnotetext{
${ }^{凶}$ Corresponding author : Muhammad Fatih Abiyyu Alamat : Universita Negeri Jakarta

Jakarta, Indonesia

E-mail : fatihabiyyu7@gmail.com
}

(C) 2021 Universitas Negeri Jakarta 


\section{PENDAHULUAN}

Tren fotografi serta perkembangan teknologi yang pesat sangat mempegaruhi bidang fotografi. Hal tersebut terlihat dari persaingan perusahaan-perusahaan produsen kamera. Menurut data Fujifilm, angka penjualan kamera mirrorless domestic mencapai 9000 - 10.000 unit per bulan.

Kecanggihan teknologi dalam fotografi menghadirkan kemudahan dalam menghasilkan sebuah foto. Sehingga menurut Peng \& Chen (2016) mengambil foto menjadi tidak hanya sederhana tetapi juga intuitif. Hal tersebut juga terlihat dari data tahun 2018, dimana diperkirakan telah lebih dari satu miliar foto telah diambil.

Selain itu, munculnya teknis dan template editing menyebabkan berkurangnya keseriusan dalam fotografi. Hal tersebut dapat terjadi karena kurang memahami usaha yang terlibat dalam fotografi tradisional atau beban risiko gagal dalam pengambilan gambar. Untuk memurnikan keaslian fotografi perlu diberi penekanan dan pelestarian terhadap teknikteknik pengambilan gambar dalam fotografi.

Semua perubahan yang terjadi dalam bidang fotografi bermuara pada perubahan instrument pembelajaran fotograif. Dimana teori dan praktik harus diterapkan secara proporsional. Teknik-teknik perlu dipraktikan secara langsung serta dikaitkan dengan konteks tertentu.

Untuk menentukan pola pembelajaran, rangakaian proses belajar perlu dirancang dan dipersiapkan. Belajar pada mahasiswa dapat terjadi karena adanya interaksi mahasiswa dengan lingkungan sekitarnya. Dengan kata lain, melakukan perancangan dan persiapan pembelajaran berarti mengkondisikan lingkungan di sekitar mahasiswa untuk mereka belajar. Gatot dan Joko (2015) menyatakan bahwa kegiatan belajar dapat dilakukan dengan baik, benar, tepat, dan berhasil optimal jika guru memiliki strategi pembelajaran yang dapat membantu siswa mengoptimalkan kegiatan belajarnya. Sehingga pemilihan strategi pembelajaran yang tepat merupakan hal yang paling penting dilakukan sebelum melakukan proses pembelajaran.
Istilah strategi dalam pembelajaran mengacu pada cara atau kegiatan-kegiatan yang dilakukan agar tujuan pembelajaran dapat berhasil dicapai. Setiap strategi pembelajaran memiliki ciri khas dan keunikan sendiri.

Di Program Studi Teknologi Pendidikan UNJ, fotografi diajarkan dalam mata kuliah Fotografi Pendidikan. Mata kuliah ini dimaksudkan untuk memberikan wawasan yang lebih luas tentang kegunaan fotografi dalam berbagai aspek kehidupan terutama dalam pendidikan. Teknologi Pendidikan fokus dalam hal memfasilitasi belajar dengan membuat, menggunakan, dan mengelola proses teknologi yang tepat guna. Kemudian keterkaitan fotografi dengan teknologi pendidikan adalah sebagai dasar pengembangan media visual maupun audiovisual.

Berdasarkan hasil survey mengenai pembelajaran mata kuliah Fotografi Pendidikan pada 30 November - 3 Desember 2019 menunjukkan bahwa sebanyak 47\% responden menganggap strategi pembelajaran yang diterapkan masih kurang sesuai. Kemudian dalam pelaksanaanya metode presentasi lebih dominan digunakan dibanding praktik langsung. Selanjutnya dari ktersediaan media, sebanyak 55,6\% responden mengeluhkan kurangnya media untuk praktik langsung. Ditambah lagi tidak tersedianya sumber belajar atau referensi sumber belajar menurut 51,1\% responden.

Dari penjelasan di atas, peneliti menggarisbawahi beberapa kendala yang dihadapi mahasiswa Teknologi Pendidikan UNJ dalam mata kuliah Fotografi Pendidikan, diantaranya: 1) Strategi pembelajaran yang digunakan belum sesuai; 2) Pembelajaran lebih dominan dilakukan dengan ceramah dan presentasi; 3) Praktik dianggap belum dilaksanakan dengan baik; 4) Kurangnya media untuk praktik teknik-teknik fotografi; dan 5) Tidak disediakannya sumber belajar maupun referensi sumber belajar. Dampak dari permasalahan tersebut adalah kurangnya pemahaman mahasiswa khususnya pada teknik-teknik fotografi sehingga menghambat penyelesaian tugas akhir.

Berangkat dari kendala yang dipaparkan di atas, peneliti memiliki pendapat bahwa perlu pengembangan strategi pembelajaran inovatif 
untuk mata kuliah Fotografi Pendidikan di Teknologi Pendidikan. Pengembangan strategi pembelajaran ini untuk mengoptimalkan integrasi antara komponen-komponen pembelajaran. Sehingga tujuan pembelajaran yang diharapkan dapat tercapai dan mahasiswa benar-benar memahami apa yang telah dipelajarinya.

\section{METODE}

Penelitian pengembangan ini menggunkan model pengembangan Dick \& Carey yang telah disesuaikan dengan keterbatasan pengembangan yang semula 10 langkah menjadi 9 langkah. Dimana kesembilan langkah tersebut meliputi: 1) Menganalisis kebutuhan untuk mengidentifikasi tujuan; 2) Menganalisis pembelajaran; 3) Menganalisis pebelajar dan konteksnya; 4) Menuliskan tujuan unjuk kerja; 5) Mengembangkan instrument penilaian; 6) Mengembangkan strategi pembelajaran; 7) Mengembangkan dan memilih bahan pembelajaran; 8) Merancang dan melakukan evaluasi formatif; dan 9) Merevisi pembelajaran.

Dalam teknik analisis data peneliti penggunakan rumus berıkut:

Jumlah Keseluruhan Skor

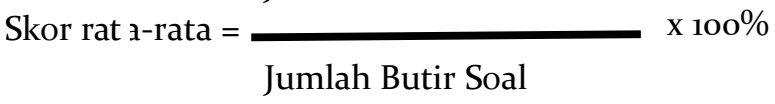

Dengan skala penilaian sebagai berikut:

Tabel 1 Skala Penilaian

\begin{tabular}{|c|c|}
\hline $3,28-4,00$ & Sangat Baik \\
\hline $2,52-3,27$ & Baik \\
\hline $1,76-2,51$ & Kurang \\
\hline $1,0-1,75$ & Sangat Kurang \\
\hline
\end{tabular}

\section{HASIL DAN PEMBAHASAN}

Pengembangan strategi pembelajaran dilakukan melalui 9 langkah model Dick \& Carey dengan penjelasan lebih rinci sebagai berikut:

\section{Menganalisis Kebutuhan untuk Mengidentifikasi Tujuan}

Langkah pertama dilakukan melalui survey analisis masalah, survey analisis kebutuhan, serta studi dokumentasi terhadap RPS mata kuliah Dasar - Dasar Fotografi dan Kurikulum Teknologi Pendidikan tahun 2019.

Dari hasil survey analisis masalah, ditemukan 6 dari 15 indikator berkaitan dengan komponen strategi pembelajaran jarang bahkan tidak pernah dilakukan. Sebagian besar terdapat di aspek pra pembelajaran dan kegiatan lanjutan. Sehingga sangat perlu dilakukan perbaikan

Kemudian hasil survey analisis kebutuhan, mendapatkan gambaran kebutuhan pebelajar terhadap pelaksanaan strategi pembelajaran kontekstual. Semua responden membutuhkan penyampaian tujuan pembelajaran dan apresepsi dalam pembelajaran untuk mendapatkan gambaran apa yang akan dipelajari. Selain itu sebanyak 92,3\% memerlukan panduan untuk belajar secara kelompok. Dan yang terpenting mereka membutuhkan peralatan untuk praktik karena sebanyak 84,4\% responden tidak memiliki kamera DSLR atau pun Mirrorless.

Terakhir, berdasarkan hasil studi dokumentasi RPS dan Kurikulum. Menghasilkan perubahan tujuan pembelajaran.

Tabel 2 Modifikasi Tujuan Umum
\begin{tabular}{|l|l|}
\multicolumn{2}{|c|}{ Tujuan Umum } \\
\hline \multicolumn{1}{|c|}{ Sebelum } & \multicolumn{1}{|c|}{ Sesudah } \\
\hline Setelah mengikuti & Setelah mempelajari \\
mata kuliah Fotografi & mata kuliah Fotografi \\
ini. Mahasiswa Jurusan & Pendidikan, \\
Teknologi Pendidikan & Mahasiswa Program \\
akan dapat melakukan & Studi Teknnologi \\
pemotretan dengan & Pendidikan mampu \\
berbagai teknik & meproduksi karya \\
fotografi & fotografi dengan \\
& berbagai teknik \\
& fotografi dengan baik. \\
\hline
\end{tabular}

\section{Menganalisis Pembelajaran}

Proses analisis pembelajaran mengasilkan peta kompetensi yang dibutuhkan untuk mencapai tujuan umum pembelajaran fotografi pendidikan. Peta kompetensi menunjukkan keterkaitan satu kompetensi dengan kompetensi yang lainnya sehingga dapat mencapai tujuan umum pembelajaran. Berikut ini merupakan hasil analisis pembelajaran: 


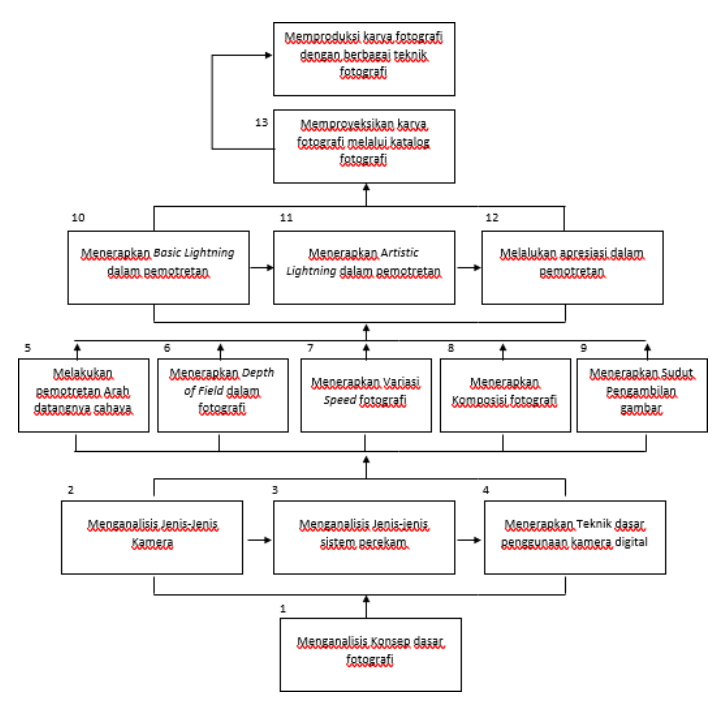

Gambar 1 Peta Kompetensi

\section{Menganalisis Pebelajar dan Konteksnya}

Langkah kegita dilakukan melalui survey dan wawancara. Aspek-aspek yang digunakan dalam analisis pebelajar dan konteks ini, meliputi: Entry skill, prior knowledge of topic area, attitude toward content, attitude toward potential delivery system, motivation of instruction (ACRS), education and ability level, general learning preference, and attitude toward organization.

Dari hasil survey tersebut menunjukkan bahwa pebelajar sudah tidak asing dengan fotografi. Sebagian besar dari mereka sering melakukannya, namun tidak mendalami teknik - tekniknya. Yang mereka ketahui hanya teknik dasar. Kemudian sebanyak 90,3\% dari responden tertarik untuk mengikuti mata kuliah fotografi. Berkaitan dengan strategi pemebelajaran, sebagian besar pebelajar menyukai belended learning dan pernah mengikuti pembelajaran secara mandiri. Selanjutnya penyampaian dosen dan materi yang menarik menjadi motivasi mereka dalam memperhatikan pembelajaran. Dari sisi gaya belajar, sebagian besar dari pebelajar memiliki gaya belajar visual-auditori dan visual kinestetik.

Kemudian dari kontek yang dalam hal ini meliputi kefeektifan pembelajaran dan fasilitas penunjang pembelajaran di teknologi pendidikan, mendapatkan rata-rata nilai 3 dari skala 5 .

\section{Menulis Tujuan Unjuk Kinerja}

Tahap ini berkesinambungan tahap analisis pembelajaran. Setelah dapat mengidentifikasi kompetensi yang diperlukan untuk mencapai tujuan umum, pengembang melakukan penulisan tujuan unjuk kerja untuk masing-masing kompetensi tersebut. Penulisan tujuan ini mengacu pada format $\mathrm{ABCD}$ (Audience, Behavior, Condition, dan Degree), dimana dalam komponen ini harus ada di setiap rumusan tujuan khusus.

Berikut ini adalah hasil dari langkah keempat:

Tabel 3 Penulisan Tujuan Khusus (Unjuk Kinerja)

\begin{tabular}{|c|c|}
\hline Kompetensi & $\begin{array}{c}\text { Tujuan pembelajaran } \\
\text { khusus }\end{array}$ \\
\hline $\begin{array}{l}\text { 1. Menganalisis } \\
\text { konsep dasar } \\
\text { fotografi }\end{array}$ & $\begin{array}{l}\text { Mahasiswa mampu } \\
\text { menganalisis konsep } \\
\text { dasar fotografi melalui } \\
\text { diskusi yang mencakup } \\
\text { pengertian, sejarah } \\
\text { singkat, tujuan, dan } \\
\text { persfektif fotografi } \\
\text { sebagai karya seni serta } \\
\text { prinsip-prinsip fotografi } \\
\text { dengan benar }\end{array}$ \\
\hline $\begin{array}{l}\text { 2. Menganalisis } \\
\text { Jenis dan } \\
\text { Krakteristik } \\
\text { Kamera }\end{array}$ & $\begin{array}{l}\text { Mahasiswa mampu } \\
\text { menganalisis jenis-jenis } \\
\text { kamera melalui diskusi } \\
\text { yang mecakup jenis-jenis, } \\
\text { karakteristik, dan fungsi- } \\
\text { fungsi bagian kamera } \\
\text { foto dengan banar }\end{array}$ \\
\hline $\begin{array}{l}\text { 3. Menganalisis } \\
\text { jenis-jenis } \\
\text { system } \\
\text { perekam }\end{array}$ & $\begin{array}{l}\text { Mahasiswa mampu } \\
\text { menganalisis jenis-jenis } \\
\text { sistem perekam melalui } \\
\text { diskusi yang mencakup } \\
\text { jenis-jenis dan } \\
\text { karakteristik sistem } \\
\text { perekam dengan benar }\end{array}$ \\
\hline $\begin{array}{l}\text { 4. Mempraktikkan } \\
\text { Teknik dasar } \\
\text { penggunaan } \\
\text { kamera digital }\end{array}$ & $\begin{array}{l}\text { Mahasiswa dapat } \\
\text { menerapkan teknik dasar } \\
\text { penggunaan kamera } \\
\text { digital melalui praktik } \\
\text { pemotretan dengan } \\
\text { benar memperhatikan } \\
\text { pengaturan fokus, } \\
\text { diafragma, dan kecepatan } \\
\text { (speed) }\end{array}$ \\
\hline $\begin{array}{l}\text { 5. Melakukan } \\
\text { pemotretan } \\
\text { dengan }\end{array}$ & $\begin{array}{l}\text { Mahasiswa dapat } \\
\text { melakukan pemotretan } \\
\text { arah datangnya cahaya }\end{array}$ \\
\hline
\end{tabular}


Muhammad Fatih Abiyyu, et. al.| JPI/Vol.o4/No.o1/2021| H. 62 - 69

\begin{tabular}{|c|c|}
\hline $\begin{array}{l}\text { memperhatikan } \\
\text { arah datangnya } \\
\text { cahaya }\end{array}$ & $\begin{array}{l}\text { melalui praktik } \\
\text { pemotretan dengan baik } \\
\text { memperhatikan sinar } \\
\text { rata, sinar samping, dan } \\
\text { sinar belakang dengan }\end{array}$ \\
\hline $\begin{array}{l}\text { Melakukan } \\
\text { pemotretan } \\
\text { depth of field }\end{array}$ & $\begin{array}{l}\text { Mahasiswa dapat } \\
\text { menerapkan depth of field } \\
\text { dalam fotografi melalui } \\
\text { praktik pemotretan } \\
\text { dengan baik } \\
\text { memperhatikan fokus } \\
\text { depan, fokus belakang, } \\
\text { dan fokus keduanya }\end{array}$ \\
\hline $\begin{array}{l}\text { 7. Melakukan } \\
\text { pemotretan } \\
\text { dengan variasi } \\
\text { speed }\end{array}$ & $\begin{array}{l}\text { Mahasiswa dapat } \\
\text { menerapkan variasi speed } \\
\text { dalam fotografi melalui } \\
\text { praktik pemotretan } \\
\text { dengan baik } \\
\text { memperhatikan variasi } \\
\text { speed B (Bulb), slow } \\
\text { speed, dan high speed }\end{array}$ \\
\hline $\begin{array}{l}\text { 8. Melakukan } \\
\text { pemotretan } \\
\text { dengan } \\
\text { komposisi }\end{array}$ & $\begin{array}{l}\text { Mahasiswa dapat } \\
\text { menerapkan komposisi } \\
\text { fotografi melalui praktik } \\
\text { pemotretan dengan baik } \\
\text { memperhatikan } \\
\text { komposisi pesan, } \\
\text { komposisi warna, dan } \\
\text { komposisi alami (candid) }\end{array}$ \\
\hline $\begin{array}{l}\text { 9. Melakukan } \\
\text { pemotretan } \\
\text { dengan } \\
\text { memperhatikan } \\
\text { sudut } \\
\text { pengambilan }\end{array}$ & $\begin{array}{l}\text { Mahasiswa dapat } \\
\text { menerapkan sudut } \\
\text { pengambilan gambar } \\
\text { dalam fotografi melalui } \\
\text { praktik pemotretan } \\
\text { dengan baik } \\
\text { memperhatikan eye level, } \\
\text { low angle, dan high angle }\end{array}$ \\
\hline $\begin{array}{l}\text { 10. Mempraktikkan } \\
\text { pemotretan } \\
\text { basic lightning }\end{array}$ & $\begin{array}{l}\text { Mahasiswa dapat } \\
\text { menerapkan basic } \\
\text { lightning fotografi } \\
\text { melalui praktik } \\
\text { pemotretan dengan baik } \\
\text { memperhatikan key light, } \\
\text { flat light, dan back light }\end{array}$ \\
\hline $\begin{array}{l}\text { 11. Mempraktikkan } \\
\text { pemotretan } \\
\text { artistic lighting }\end{array}$ & $\begin{array}{l}\text { Mahasiswa dapat } \\
\text { menerapkan artistic } \\
\text { lighting fotografi melalui } \\
\text { praktik pemotretan } \\
\text { dengan baik } \\
\text { memperhatikan soft } \\
\text { lighting, hard lighting, } \\
\text { dan effect lighting }\end{array}$ \\
\hline $\begin{array}{l}\text { 12. Mempraktikkan } \\
\text { apresiasi dalam }\end{array}$ & $\begin{array}{l}\text { Mahasiswa dapat } \\
\text { melakukan apresiasi }\end{array}$ \\
\hline
\end{tabular}

\begin{tabular}{|l|l}
\hline pemotretan & $\begin{array}{l}\text { dalam fotografi melalui } \\
\text { praktik pemotretan } \\
\text { dengan baik } \\
\text { meperhatikan } \\
\text { pemotretan interior, } \\
\text { model, tekstur, dan } \\
\text { perilaku binatang } \\
\text { (animal behavior) }\end{array}$ \\
$\begin{array}{l}\text { 13. Melakukan } \\
\text { unjuk karya } \\
\text { dalam bentuk } \\
\text { portfolio kreatif }\end{array}$ & $\begin{array}{l}\text { Mahasiswa dapat } \\
\text { memproyeksikan karya } \\
\text { berbagai teknik fotografi } \\
\text { melalui katalog fotografi } \\
\text { yang mencakup semua } \\
\text { teknik fotografi dengan } \\
\text { baik }\end{array}$ \\
\hline
\end{tabular}

\section{Mengembangkan Instrumen Penilaian}

Pelaksanaan tahap ini mengacu pada prinsip pembelajaran kontekstual dimana penilaikan dilakukan dengan melakukan penilaian sebenarnya (authentic assessment). Sehingga dilakukan pengembangan daftar cek tugas, serta rubrik penilaian tugas dan kinerja sebagai instrumen untuk melakukan penilaian sebenarnya

\section{Mengembangkan Strategi Pembelajaran}

Pada tahap pengembangan strategi pembelajaran pengembang menerapkan komponen-komponen strategi pembelajaran yang dikemukakan oleh Dick \& Carey yang meliputi: kegiatan pra pembelajaran, penyampaian informasi, partisipasi peserta didik, penilaian, dan kegiatan lanjutan.

Komponen-komponen tersebut dijadikan sebagai kerangka penyusunan aktivitas pembelajaran. Dari kerangka tersebut

kemudian dikembangkan menjadi langkahlangkah pembelajaran yang lebih sepesifik serta menerapkan prinsip pembelajaran kontekstual.

Berikut salah satu strategi pembelajaran untuk topik membaca arah cahaya:

Tabel 4 Strategi Pembelajaran

\begin{tabular}{ll}
\hline Pra-Pembelajaran & \\
\hline 1. & Dosen membuka pembelajaran dengan \\
& salam, menyapa mahasiswa dan \\
& bertanya kabar
\end{tabular}

(Konstruktivisme)

2. Dosen bertanya kepada mahasiswa: - Kalian pasti tahu, sinar matahari 
pagi, siang dan sore pasti mengahasilkan arah bayangan yang berbeda. Tapi tahu ga kenapa arah bayangannya bisa berbeda?

3. Dosen memberikan gambaran mengenai perubahan arah cahaya pada foto dapat merubah kesan terhadap foto

4. Dosen menjelaskan tujuan pembelajaran yang akan dicapai

Penyampaian Informasi

(Pemodelan)

1. Dosen menunjukkan hasil foto flat, side, dan back light yang memiliki kesan berbeda

2. Mahasiswa memperhatikan foto yang ditampilkan

3. Dosen menjelaskan pentingnya arah cahaya dalam fotografi

4. Dosen menjelaskan ciri-ciri yang harus diperhatikan dari foto flat light, side light, dan back light

\section{(Bertanya)}

5. Dosen memberikan pertanyaan berikut ini kepada mahasiswa:

- Bagaimana cara menghasilkan foto dengan cahaya rata?

- Bagaimana cara menghasilkan foto dengan cahaya samping?

- Bagaimana cara menghasilkan foto dengan cahaya belakang?

5. Dosen meminta perwakilan mahasiswa untuk menjawab masing-masing dari setiap pertanyaan yang diajukan

\begin{tabular}{l} 
Partisipasi Peserta Didik \\
\hline (Komunitas Belajar) \\
1. Dosen memandu mahasiswa untuk \\
membentuk kelompok dengan jumlah \\
anggota sebanyak 4 orang untuk \\
mendiskusikan pertanyaan-pertanyaan \\
tersebut \\
2. Dosen menjelaskan panduan untuk \\
diskusi kelompok yang akan dilakukan
\end{tabular}

(Inkuiri)

3. Mahasiswa secara berkelompok berdiskusi melakukan kajian mengenai cara melakukan pemotretan flat, side, dan back light

4. Mahasiswa mendemonstrasikan hasil diskusi kelompoknya

5. Mahasiswa membuat kesimpulan dari jawaban hasil diskusi kelompok dan

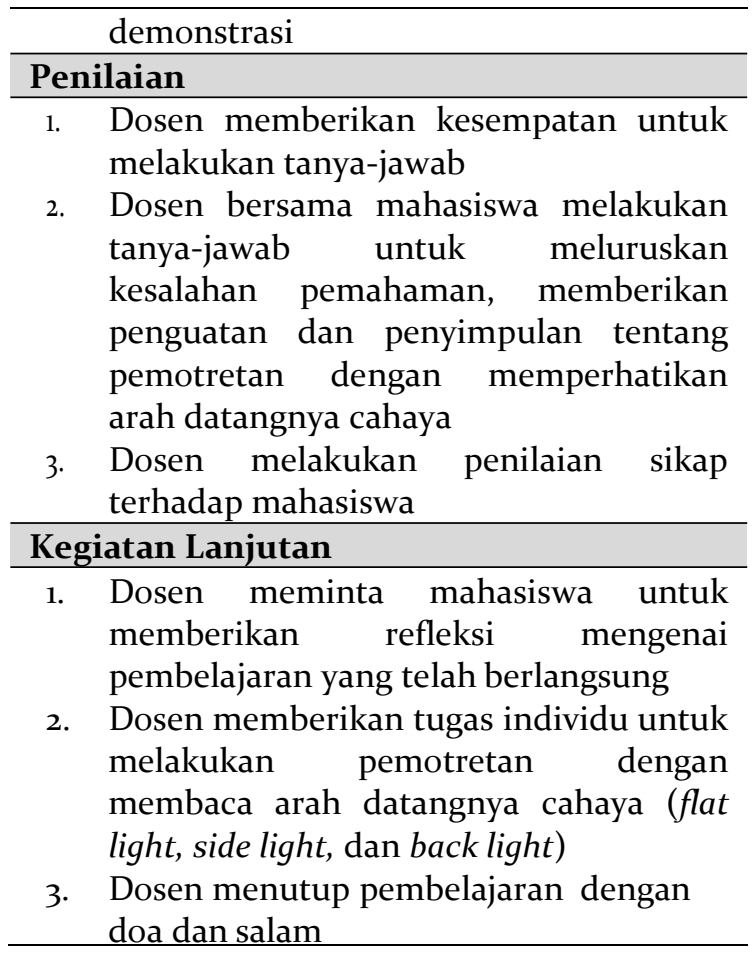

\section{Mengembangkan dan Memilih Bahan Pembelajaran}

Untuk mendukung strategi pembelajaran yang telah dikembangkan perlu tersedia bahan pmebelajaran. Oleh karena itu dikembangkan bahan pembelajaran berupa modul satuan pembelajaran. Modul ini dikembangkan untuk mencapai satu tujuan khusus pembelajaran.
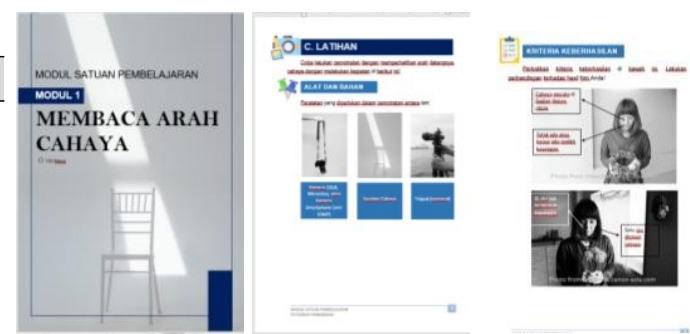

Gambar 2 Modul Satuan Pembelajaran

\section{Merencanakan dan Melakukan Evaluasi Formatif}

Pada tahap ini pengembang melakukan evaluasi formatif terhadap produk yang dihasilkan yaitu RPS Mata Kuliah Fotografi Pendidikan dan Modul Satuan Pembelajaran. Evaluasi yang dilakukan melalui dua tahap, yaitu : expert review dan one to one. Berikuti ini hasil evaluasi yang pengembang lakukan:
a. Expert Review 
- Ahli Desain Pembelajaran

Expert review ahli desain pembelajaran dilakukan oleh Bapak Erry Utomo, Ph.D. Berdasarkan hasil expert review oleh ahli desain pembelajaran rata-rata yang diperoleh dari expert review ahli pembelajaran adalah 3,75. Dalam acuan skala penilaian yang digunakan termasuk kategori sangat baik.

- Ahli Materi

Expert review ahli materi dilakukan oleh Bapak Dr.Uwes Anis Chaeruman, M.Pd selaku dosen teknologi pendidikan. Berdasarkan expert review ahli materi rata-rata yang diperoleh dari expert review ahli materi adalah 2,9. Dalam acuan skala penilaian yang digunakan termasuk kategori baik.

- Ahli Media

Expert review ahli media dilakukan oleh Bapak Kunto Imbar Nursetyo, S.Pd, M.Pd sebagai dosen media di Teknologi Pendidikan UNJ. Berdasarkan expert review ahli media rata-rata yang diperoleh dari expert review ahli media adalah 3,87. Dalam acuan skala penilaian yang digunakan termasuk kategori sangat baik.

Tabel 5 Hasil Rata-Rata Keseluruhan Expert Review

\begin{tabular}{lc}
\multicolumn{1}{c}{ Expert Review } & Rata-Rata \\
\hline Ahli Desain Pembelajaran & 3,75 \\
Ahli Materi & $\mathbf{2 , 9}$ \\
Ahli Media & 3,87 \\
Rata-rata Keseluruhan & $\mathbf{3 , 5}$ \\
\hline
\end{tabular}

b. One to One

Pada tahap ini pengembang melibatkan dosen pengampu mata kuliah fotografi Pendidikan dan mahasiswa teknologi Pendidikan tahun angkatan 2017-2018 sebanyak 3 orang.

Evaluasi pengguna dilakukan oleh Bapak Dr. Robinson Situmorang selaku dosen pengampu mata kuliah fotografi
Pendidikan mendapatkan rata-rata nilai 3,57. Dalam skala penilaian termasuk kategori sangat baik.

Selanjutnya evaluasi one to one dilakukan oleh Siti Sofiah, Shaffiya Rashida Andinnari, dan Muhamad Ghazi Iman Hawali. Berdasarkan evaluasi tersebut rata-rata skor yang diperoleh adalah 3,7. Dalam skala penilaian termasuk kategori sangat baik.

\begin{tabular}{lc}
\multicolumn{2}{c}{ Tabel 6 Hasil Rata-Rata One to One } \\
\hline \multicolumn{1}{c}{ One to One } & Rata-Rata \\
\hline Dosen Pengampu & 3,57 \\
Mahasiswa & 3,7 \\
Rata-Rata Keseluruhan & $\mathbf{3 , 6}$ \\
\hline
\end{tabular}

\section{Merevisi Pembelajaran}

Pada langkah terakhir ini peneliti melakukan revisi berdasarkan hasil evaluasi formatif. Adapun hal-hal yang dialakukan dalam tahap revisi adalah sebagai berikut:

a. Memperjelas Latihan dalam Langkah pembelajaran

b. Menambahkan kegiatan pemecahan masalah dalam langkah pembelajaran

c. Menjelaskan alasan penggunaan skala penilaian 7,8 , dan 9 serta memeperinci indikator penilaian.

d. Memperbaiki Langkah-langkah pembelajaran sesuai dengan pendapat Dick \& Carey.

e. Untuk modul satuan pembelajaran dilakukan perbaikan terhadap layout, style penyajian grafis, kesalahan penulisan, serta mengintegrasikan dengan sumber belajar lain.

\section{SIMPULAN}

Penelitian pengembangan ini menghasilkan Rencana Peerkuliahan Semester (RPS) mata kuliah fotografi pendidikan dengan menerapkan strategi pembelajaran kontekstual dan modul satuan pembelajaran untuk pokok bahasan membaca arah cahaya. Penelitian ini menggunakan model Dick \& Carey, dengan melakukan evaluasi formatif berupa expert review dan one to one. Dari hasil evaluasi formatif yang dilakukan dapat ditarik kesimpulan bahwa produk yang dihasilkan dari penelitian ini sangat baik. 


\section{UCAPAN TERIMA KASIH}

Alhamdulillah. Rasa syukur peneliti panjatkan kepada Allah subhanahu wa ta'ala. Kemudian kepada keluarga dan sahabat yang selalu mendukung. Tentunya kepada dosen pembimbing dan penguji yang telah memberikan feedback positif terhadap proses pengembangan ini.

\section{DAFTAR PUSTAKA}

Barbara, Seels, dan Richey, R. C. 1994. Instructional Technology: The Definition and Domain of the Field. Washington: AECT.

Emzir. 2008. Metodologi Penelitian Pendidikan Kuantitatif dan Kualitatif. Depok: Rajagrafindo Persada.

Husein, S., Gunawan, Harjono, A., dan Wahyuni, S. 2019. Problem-Based Learning with Interactive Multimedia to Improve Student Understanding of Thermodynamic. Journal of Physics: Conference Series.

Nasution, W. N. 2017. Strategi Pembelajaran. Medan: Perdana Publishing.

Peng, L.-H., dan Chen, S.-H. 2016. Integrating Creative Photography Pedagogy in General Education. Social and Behavioral Science, 183-191.

Prawiradilaga, D. S. 2007. Prinsip Disain Pembelajaran. Jakarta: Kencana Prenada Media Group.

Prawiradilaga, D. S. 2012. Wawasan Teknologi Pendidikan. Jakarta: Kencana Prenada Media Group.

Rafida, T. 2016. Observing Contextual Teaching and Learning on Student' Achievement in Writing Recount Text: Case Study SMP Swasta Bina Bangsa Batubara Regency. International Journal of English Language Teaching, 57-68.

Siregar, E., dan Nara, H. 2010. Teori Belajar dan Pembelajaran. Jakarta: Ghalia Indonesia.

Suryawati, E., Osman, K., dan Meerah, T. M. 2010. The Effectiveness of RANGKA
Contextual Teaching and Learning on Student' Problem Solving Skills and Scientific Attitude. Social and Behavioral Science, 1717-1721.

Widodo, G., dan Joko. 2015, Februari 1. Pengembangan dan Implementasi Perangkat Pembelajaran Berbasis Proyek. INVOTEC, XI, 41-56.

http://staffnew.uny.ac.id/upload/132304795/pen elitian/Desain+Pembelajaran-pekerti.pdf" http://staffnew.uny.ac.id/upload/132304795/pen elitian/Desain+Pembelajaran-pekerti.pdf, diakses pada 8 Januari 2020

http://www.pustaka.ut.ac.id/lib/wpcontent/uploads/pdfmk/PBIN4301-M1.pdf" http://www.pustaka.ut.ac.id/lib/wpcontent/uploads/pdfmk/PBIN4301-M1.pdf, diakses pada 8 Januari 2020

https://educationaltechnology.net/kempdesign-model/ diakses pada 4 Februari 2020

https://www.instructionaldesign.org/models/ad die/" https://www.instructionaldesign.org/models/ad die/ diakses pada 8 Januari 2020

Implementasi Pengembangan Kecakapan Abad 21 Melalui Fitur Kelas Maya Portal Rumah Belajar. http://pena.belajar.kemendikbud.go.id" http://pena.belajar.kemendikbud.go.id 2018/og/implementasi-pengembangankecakapan-abad-21-melalui-kelas-maya-portalrumah-belajar/diakses pada 5 Januari 2020

Theconversation, "Of the Trillion Photo Taken in 2018, Which Were the Most Memorable?" HYPERLINK "http://theconversation.com/ofthe-trillion-photos-taken-in-2018-which-werethe-most-memorable-108815" http://theconversation.com/of-the-trillionphotos-taken-in-2018-which-were-the-mostmemorable-108815 diakses pada 1 Desember 2019 